\title{
Cowpea-Meloidogyne incognita interaction: Root proteomic analysis during early stages of nematode infection
}

\author{
Gabriela R. C. Villeth ${ }^{1 *}$, Lilian S. T. Carmo ${ }^{1 *}$, Luciano P. Silva ${ }^{1}$, Wagner Fontes $^{2}$, \\ Priscila Grynberg ${ }^{1}$, Mario Saraiva ${ }^{2}$, Ana C. M. Brasileiro ${ }^{1}$, Regina M. D. Carneiro ${ }^{1}$, \\ José T. A. Oliveira ${ }^{3}$, Maria F. Grossi-de-Sá ${ }^{1}$ and Angela Mehta ${ }^{1}$ \\ ${ }^{1}$ Embrapa Recursos Genéticos e Biotecnologia, Brasília, DF, Brazil \\ ${ }^{2}$ Universidade de Brasília, Brasília, DF, Brazil \\ ${ }^{3}$ Universidade Federal do Ceará, Fortaleza, CE, Brazil
}

Cowpea (Vigna unguiculata L. Walp) is an important legume species well adapted to low fertility soils and prolonged drought periods. One of the main problems that cause severe yield losses in cowpea is the root-knot nematode Meloidogyne incognita. The aim of this work was to analyze the differential expression of proteins in the contrasting cultivars of cowpea CE 31 (highly resistant) and CE 109 (slightly resistant) during early stages of $M$. incognita infection. Cowpea roots were collected at 3, 6, and 9 days after inoculation and used for protein extraction and 2-DE analysis. From a total of 59 differential spots, 37 proteins were identified, mostly involved in plant defense, such as spermidine synthase, patatin, proteasome component, and nitrile-specifier protein. A follow-up study was performed by quantitative RT-PCR analysis of nine selected proteins and the results revealed a very similar upregulation trend between the protein expression profiles and the corresponding transcripts. This study also identified ACT and GAPDH as a good combination of reference genes for quantitative RT-PCR analysis of the pathosystem cowpea/nematode. Additionally, an interactome analysis showed three major pathways affected by nematode infection: proteasome endopeptidase complex, oxidative phosphorylation, and flavonoid biosynthesis. Taken together, the results obtained by proteome, transcriptome, and interactome approaches suggest that oxidative stress, ubiquitination, and glucosinolate degradation may be part of cowpea CE 31 resistance mechanisms in response to nematode infection.

\section{Keywords:}

2-DE / Differential expression / MS / Nematode-plant interaction / Plant proteomics

Additional supporting information may be found in the online version of this article at the publisher's web-site

\footnotetext{
Correspondence: Dr. Angela Mehta, Embrapa Recursos Genéticos e Biotecnologia, PBI, Av. W/5 Norte Final, CEP 70770-917, Brasília, DF, Brazil

E-mail: angela.mehta@embrapa.br

Fax: +55 (61) 3340-3658
}

\begin{abstract}
Abbreviations: DAI, days after inoculation; HR, hypersensitive response; LSU, large subunit; qRT-PCR, quantitative RT-PCR; RKN, root-knot nematodes; UPS, Ubiquitin/26S proteasome degradation system
\end{abstract}

Received: November 24, 2014 Revised: February 13, 2015 Accepted: February 26, 2015

\section{Introduction}

Cowpea (Vigna unguiculata L. Walp) is an important legume crop, adapted throughout its evolution to a vast range of climate conditions such as drought, high humidity, and extreme temperatures. This crop grows in warm and hot regions worldwide, mainly in tropical areas of Africa, Asia, Southern Europe, and Central/South America where it is broadly consumed. Cowpea beans are considered a highly nutritious

*These authors contributed equally to this work.

Colour online: See the article online to view Figs. 2 and 3 in colour. 
legume with antioxidant properties since it is rich in minerals, vitamins, and folic acid (vitamin B9) [1]. Moreover, cowpea dry beans can be stored, rapidly cooked, and eaten in many forms, which are considered important aspects for populations living in poverty.

In Brazil, the production of cowpea beans is mainly concentrated in the North and Northeast regions which are low fertility soil and semiarid zones, respectively. However, expansion to tropical savannah zones of the country, characterized by a marked dry season during winter, has been recently observed. In contrast to its high ability to adapt to adverse environmental conditions such as drought, heat, and salt stresses $[2,3]$, cowpea harbors low resistance to biotic stresses and can be severely attacked by different pathogens such as bacteria, virus, and nematodes, especially the root-knot nematodes (RKN) Meloidogyne spp. [4]. RKN are highly polyphagous plant pathogens and are responsible for severe yield losses in many economically important crops worldwide, such as cotton, soybean, and coffee, and the gall nematode $M$. incognita is considered the most destructive species [5,6]. Meloidogyne incognita colonizes plant roots leading to a loss in the efficiency of water and nutrients uptake by the root system that causes symptoms similar to nutritional deficiency, such as reduced vigor with smaller leaves. The control of RKN parasites occurs mainly by the application of soil nematicides, which are usually inefficient, expensive, and extremely harmful to human and animal health as well as to the environment. The use of resistant plants, associated with integrated pest management programs, has been considered one of the main alternatives for nematode control, minimizing the harmful effects of toxic agrochemicals.

Resistance (R) genes that confer resistance to nematodes have been mapped and identified in different plant species $[7,8]$. These R-genes mediate highly specific pathogen recognition in compatible or incompatible plant-RKN interaction. The first RKN R-gene described was Mi-1.2 from tomato (Solanum lycopersicum) that belongs to the nucleotide bindingleucine-rich repeats (LRR) family of plant R-gene-associated products [9]. In cowpea, a dominant single R-gene or locus $(R k)$ for resistance to $M$. incognita and other RKNs was also described [10], but it seems that the resistance conferred by $\mathrm{Rk}$ is not effective to some RKN populations [11].

Studies on global gene expression and protein accumulation are interesting approaches to identify genes involved in resistance and may be a valuable resource for the characterization of new alleles leading to the development of cultivars with a broader resistance/tolerance against nematodes. Molecular studies have shown that intense gene expression changes occur in response to nematode infection [12-14], particularly in the early stages after pathogen perception. One strategy used for discovering potential candidates for nematode resistance is by analyzing the proteome of infected plants by 2-DE, which is a classical approach routinely used in proteomic studies. Although 2-DE has been widely applied in the field of plant-pathogen interactions, only few proteins from host-nematode interactions were identified to date by pro- teomic surveys [15]. Considering the need to better understand the molecular processes trigged after nematode infection, particularly in resistant plant genotypes, we have investigated the proteomic changes in two contrasting cowpea cultivars [16] infected with the RKN M. incognita in an attempt to identify genes and proteins involved in resistance/defense. Additionally, gene expression profiling by quantitative RTPCR (qRT-PCR) of some identified proteins and interactome analysis were also performed to complement the proteomic study and help understand the cowpea resistance mechanisms triggered in response to RKN infection.

\section{Materials and methods}

\subsection{Plant material and nematode challenge}

Meloidogyne incognita population was maintained in tomato roots under greenhouse conditions for approximately 3 months. After this period, roots were washed and triturated in a blender with $0.5 \% \mathrm{v} / \mathrm{v}$ sodium hypochlorite to extract nematodes, as previously described [17]. Freshly hatched secondstage juveniles (J2) were collected using modified Baermann funnels and nematode counting was done under a light microscope using Peter's counting slides. Cowpea plants from CE 31 and CE 109 cultivars, previously classified [16] as highly and slightly nematode resistant, respectively, were challenged with 5.000 M. incognita J2 in three independent experiments (biological replicates). Infected cowpea roots were collected at 3,6, and 9 days after inoculation (DAI), all early stages of infection, as indicated by previous studies $[16,18]$, ground in liquid nitrogen and stored at $-80^{\circ} \mathrm{C}$.

\subsection{Protein extraction and 2-DE analysis}

Infected cowpea roots collected at 3, 6, and 9 DAI were pooled for each cultivar and used for protein extraction with phenol, as previously described [19] and suspended in solubilization buffer (7 M urea; $1 \mathrm{M}$ thiourea; 4\% w/v CHAPS; 2\% v/v IPG buffer pH 4-7; 40 mM DTT). Protein quantification was performed using the Protein Assay Dye Reagent Concentrate (Bio-Rad), according to the manufacturer's instructions. Approximately $400 \mu \mathrm{g}$ of extracted proteins were used to rehydrate $11 \mathrm{~cm}$ Immobiline DryStrips, $\mathrm{pH} \mathrm{4-7} \mathrm{for}$ $16 \mathrm{~h}$. IEF was performed using a Multiphor II Electrophoresis system (GE Healthcare), according to the manufacturer's instructions (phase 1: $300 \mathrm{~V}, 2 \mathrm{~mA}, 5 \mathrm{~W}, 0: 01 \mathrm{~h}$; phase 2: $3500 \mathrm{~V}, 2 \mathrm{~mA}, 5 \mathrm{~W}, 1: 30 \mathrm{~h}$; phase 3: $3.500 \mathrm{~V}, 2 \mathrm{~mA}, 5 \mathrm{~W}$, 3:00 h). IPG strips were maintained in equilibration buffer (1.5 M Tris- $\mathrm{HCl} \mathrm{pH} 8.8 ; 6 \mathrm{M}$ urea; $30 \%$ v/v glycerol; $2 \%$ $\mathrm{w} / \mathrm{v}$ SDS; $1 \% \mathrm{v} / \mathrm{v}$ bromophenol blue) with 1 M DTT for $15 \mathrm{~min}$ followed by additional $15 \mathrm{~min}$ in the same buffer containing $2.5 \% \mathrm{w} / \mathrm{v}$ iodoacetamide. The second dimension was performed using $10 \% \mathrm{w} / \mathrm{v}$ polyacrylamide gels and the electrophoresis was run in a vertical system (Biometra V2) with glycine buffer $(20 \mathrm{mM}$ Tris- $\mathrm{HCl} \mathrm{pH} 8.3,192 \mu \mathrm{M}$ glycine, 
and $0.1 \% \mathrm{w} / \mathrm{v} \mathrm{SDS}$ ) and the molecular mass marker "Benchmark Protein Ladder" (Invitrogen). Gels were stained with colloidal Coomassie Blue $(0.1 \% \mathrm{w} / \mathrm{v}$ Coomassie G250; $2 \%$ $\mathrm{v} / \mathrm{v}$ phosphoric acid; $10 \% \mathrm{w} / \mathrm{v}$ ammonium sulphate, and $20 \% \mathrm{v} / \mathrm{v}$ methanol) and at least four gels from each of the three biological replicates were digitalized with the ImageScanner III (GE Healthcare). One gel from each biological replicate was analyzed using the software Image Master 2D Platinum version 7.05 (GE Healthcare). Spots were automatically detected and a manual adjustment was performed to minimize technical artifacts. Automated matching was performed and matches were manually checked in order to minimize possible errors. Only proteins present in at least two out of three replicates were considered for analysis. Proteins were considered as differentially expressed only when differences were significant by Student's $t$-test at a significance level of $95 \%$.

\subsection{Protein identification}

Differentially expressed proteins were excised from the gels and hydrolyzed with trypsin using the Trypsin Profile IGD kit (Sigma), according to the manufacturer's instructions. Gel spots were submitted to hydrolysis at $37^{\circ} \mathrm{C}$ for $19-22 \mathrm{~h}$ and $1 \mu \mathrm{L}$ of the hydrolyzed solution was mixed with $1 \mu \mathrm{L}$ of alpha-cyano-4-hydroxycinnamic acid $(10 \mathrm{mg} / \mathrm{mL}$ dissolved in $50 \% \mathrm{v} / \mathrm{v}$ ACN and $0.1 \% \mathrm{v} / \mathrm{v}$ TFA) and applied manually onto an Anchorchip 800/384 MALDI target plate. Peptides were analyzed using UltraFlex III or AutoFlex Speed MALDI TOF-TOF mass spectrometers (Bruker Daltonics) operating in positive reflector (MS) and LIFT (MS/MS) modes.

MS and MS/MS peak lists were generated using the FlexAnalysis 3.3 software (Bruker Daltonics) and individually searched using the MASCOT search engine (Matrix Science) with the NCBInr protein database against all entries, Viridiplantae (or plant ESTs), Caenorhabditis elegans and other Metazoa. When a positive identification to Viridiplantae was obtained, an additional search of the unmatched proteins was performed against $C$. elegans and other Metazoa in order to verify the presence of nematode proteins in protein mixtures. The protein identification parameters for PMF searches were as follows: 150 ppm mass tolerance, one missed cleavage, and carbamidomethylation of cysteine residues as fixed modification and oxidation of methionine residues as variable modification. For MS/MS, the parameters used were the same described for PMF with an ion mass tolerance of $0.6 \mathrm{Da}$ and charge state +1 . When $\mathrm{p} I$ and molecular weight were not available, these values were calculated using ExPASy Compute $\mathrm{p} I /$ molecular weight tool (http://ca.expasy.org/tools/pi_tool.html). The cutoff value for the Probability Based Mowse score calculated by MASCOT (at $p<0.05)$ was used to accept the identification. When only single peptides were identified, the sequence generated by the MASCOT program was checked by manual De novo sequencing with the help of FlexAnalysis 3.3 software (Bruker
Daltonics). Some protein spots not identified by MALDI TOFTOF were submitted to LC-MS. The peptide mixture eluted from the gel was desalted in a Poros R2 (Applied Biosystems) microcolumn, packed in a gel loader pipette tip. Peptides were separated using a Dionex Ultimate 3000 (Thermo Scientific) chromatographic system with a linear gradient of 5-35\% solvent $\mathrm{B}(0.1 \% \mathrm{w} / \mathrm{v}$ formic acid in $\mathrm{ACN})$ in $15 \mathrm{~min}$ at a flow rate of $250 \mathrm{~nL} / \mathrm{min}$ on a $\mathrm{C}_{18}$ reversed phase column $(75 \mu \mathrm{m}$ $\times 15 \mathrm{~cm}$ ). Peptides were eluted directly to an Orbitrap Elite mass spectrometer (Thermo Scientific). The mass spectrometer performed a full spectrum scan from $\mathrm{m} / \mathrm{z} 350$ to 1650 at a resolution of 120.000 , and then the 15 most intense ions were fragmented by high energy collision dissociation approach. The fragment ions were detected at a resolution of 15000 ; dynamic exclusion was set to $10 \mathrm{~s}$; and charge states assigned as single or unassigned were rejected.

The resulting raw files containing MS and MS/MS data were analyzed using Peaks v.7 [20] and MaxQuant v.1.4.1.2 [21] against the NCBI EST database, filtered by the taxonomy ID 3917 applying standard settings. The precursor mass tolerance was $15 \mathrm{ppm}$ and the fragment mass tolerance was $0.1 \mathrm{Da}$. Two missing cleavages were allowed and carbamidomethylation $(\mathrm{C})$, oxidation $(\mathrm{M})$, and acetylation (N-term) were also allowed as modifications. The list of identified proteins was filtered by FDR $<0.01$ at the peptide level and presence of at least two unique peptides. Identified proteins were sorted based on intensity and when the most abundant protein was ten times over the second abundant protein, it was selected as a positively identified protein.

\subsection{RNA extraction and cDNA synthesis}

Total RNA was extracted from infected CE 31 roots at 3, 6, and 9 DAI and from noninoculated control using the RNeasy Plant Mini Kit (Qiagen), according to the manufacturer's instructions. RNA quality/integrity was checked on ethidium bromide stained $1.5 \% \mathrm{w} / \mathrm{v}$ agarose gel and quantified using NanoDrop ${ }^{\circledR}$ ND-1000 spectrophotometer (Thermo Scientific). RNA samples were subsequently treated with DNase (TURBO DNA-free, Ambion), according to manufacturer's instructions. For cDNA synthesis, $2 \mu \mathrm{g}$ of treated total RNA was mixed with $500 \mathrm{ng}$ oligo $\mathrm{d}(\mathrm{T})$ primer and $0.5 \mathrm{mM} \mathrm{dNTP}$ and the reaction was incubated for $5 \mathrm{~min}$ at $65^{\circ} \mathrm{C}$. A total of $4 \mu \mathrm{L} 5 \times$ First strand buffer, $1 \mu \mathrm{L} 10 \mathrm{mM}$ DTT, and $1 \mu \mathrm{L}$ Superscript Reverse Transcriptase III (200 U/ $\mu \mathrm{L}$; Invitrogen) were added and the reaction incubated for $60 \mathrm{~min}$ at $50^{\circ} \mathrm{C}$, followed by $15 \mathrm{~min}$ at $70^{\circ} \mathrm{C}$.

\subsection{Primer design and qRT-PCR analysis}

Proteins were selected from the proteome analysis here obtained (six proteins) and from previous unpublished studies performed by our group (three proteins) for a follow-up study of gene expression by qRT-PCR analysis. The nucleotide sequences of transcripts corresponding to the selected proteins 
was obtained by performing a TBLASTN search using the protein sequence identified by the MASCOT program against the NCBI EST database of V. unguiculata. For each candidate gene, primers were designed using Primer 3 Plus software [22] and its specificity confirmed using BLASTN searches on Vigna spp. transcript database resources (EST and TSA) from NCBI. Primer sequences, length of amplicons, and source of sequences are listed in Supporting Information Table 1.

qRT-PCR reactions were conducted using the Platinum ${ }^{\circledR}$ SYBR $^{\circledR}$ Green qPCR Super Mix-UDGw/ROX kit (Invitrogen), in two biological and three technical replicates, as previously described [23], on a StepOnePlus ${ }^{\mathrm{TM}}$ Real-Time PCR System (Applied Biosystems). Primer efficiency and optimal cycle threshold $\left(C_{\mathrm{q}}\right)$ values were estimated using the online realtime PCR Miner tool [24]. Average $C_{q}$ values were normalized using two reference genes: an actin (ACT), previously identified as reference gene in $V$. radiata [25], and a glyceraldehyde 3-phosphate dehydrogenase (GAPDH), identified as stably expressed in previous qRT-PCR analysis conducted in $V$. unguiculata roots in our laboratory (unpublished data). Expression ratios of mRNA transcripts at 3,6, and 9 DAI, relative to control condition (day 0 ), were calculated and statistically tested using REST 2009 v. 2.0.13 software [26].

\subsection{In silico prediction of protein-protein interactions}

The protein-protein interaction network of differentially expressed proteins was predicted from Arabidopsis thaliana proteins homologous to V. unguiculata using String v. 9.1 (http://string-db.org/) with default parameters (medium confidence) and GeneMania [27] with co-expression evidences. No more than 20 interactions were allowed to predict the interactions between the $V$. unguiculata differentially expressed proteins and other A. thaliana proteins. GeneMania was used to complement the network predicted with String v. 9.1 since this software retrieves information from a different database (NCBI's GEO). The Arabidopsis Information Resource (TAIR) was used to define the locus and extract gene ontology annotations.

\section{Results and discussion}

The complex interaction between the host plants and the parasitic nematodes has been widely studied in the search for more efficient strategies to control this important agricultural pest. Although the use of transcriptomic approaches to analyze global gene expression in nematode infected plants has been reported for many hosts, proteomic methods have been rarely employed $[15,18,28]$. In this study, we used 2-DE analysis to identify proteins differentially accumulated in two contrasting cowpea cultivars (highly M. incognita-resistant CE 31 and slightly $M$. incognita-resistant CE 109, as determined by Oliveira et al. [16,18]) in response to nematode inoculation. In a previous field study, Oliveira et al. [16] classified ten cowpea cultivars according to nematode resistance and showed that the most numerous $M$. incognita egg masses were present in the root system of CE 109 cultivar $(41.3 \pm 16.5)$ whereas in CE 31 such values were much lower $(0.7 \pm 0.4)$. These data allowed distinguishing these two contrasting cultivars, used in the present work, as highly and slightly M. incognita resistant, respectively, according to Sasser et al. [29].

Oliveira et al. $[16,18]$ also analyzed the kinetics of antioxidant enzymes and protein accumulation in these contrasting cultivars and showed that the antioxidant enzyme superoxide dismutase increased and catalase decreased in CE 31, leading to accumulation of hydrogen peroxide in inoculated roots in comparison to the noninoculated control, from 2 DAI. Moreover, the pathogenesis-related proteins chitinase, $\beta$ 1,3-glucanase, peroxidase, and cysteine proteinase inhibitor increased in CE 31 cultivar in comparison to CE 109 at 2 DAI with $M$. incognita. These changes persisted up to the end of the experimental period (10 DAI) and were associated to the smaller final population of M. incognita in CE 31. Based on these previous results, we have sampled CE 31 challenged roots at 3,6, and 9 DAI for proteomic and transcriptomic analysis.

In the present study, the analysis of the obtained 2-DE maps from both cultivars showed approximately 500 protein spots per gel, varying in mass from 10 to $160 \mathrm{kDa}$ and in $\mathrm{pI}$ from 4 to 7 (Fig. 1). The comparative analysis between CE 31 and CE 109 showed a total of 59 differential proteins, including 13 unique to CE 31 and 15 to CE 109, as well as 18 increased and 13 decreased in CE 31 (Fig. 1; Supporting Information Table 2). Some of the differential spots were very small and could hardly be individualized and therefore were not excised for identification by MS. Other spots did not return reliable MS identification probably due to reduced ionization capacity or absence of information in the database. Therefore, from the 59 differential proteins, 37 (63\%) could be identified by MS (Table 1; Supporting Information Tables 2 and 3). Interestingly, four of the 37 differential spots (spots 313, 352, 436, and 520) were identified as a mixture of plant and nematode proteins (Table 1 and Supporting Information Table 3). It is expected that the amount of plant material present in inoculated cowpea root samples is much higher than that of the nematode. However, the detection of nematode proteins in root samples indicates that it is also important to perform searches against the infecting organism even if the study aims at plant proteins. In the case of spot 352 (increased in CE 31) and spot 520 (unique to CE 31 ), it is probable that the difference in protein abundance may indeed correspond to the plant proteins, since the transcriptomic analysis, performed with specific primers for plant genes, confirmed the upregulation, as discussed below. For the two other spots, which were increased (spot 313) and unique (spot 436) to CE 109, additional studies need to be performed, since we cannot determine which protein, if any, is being differentially expressed. 

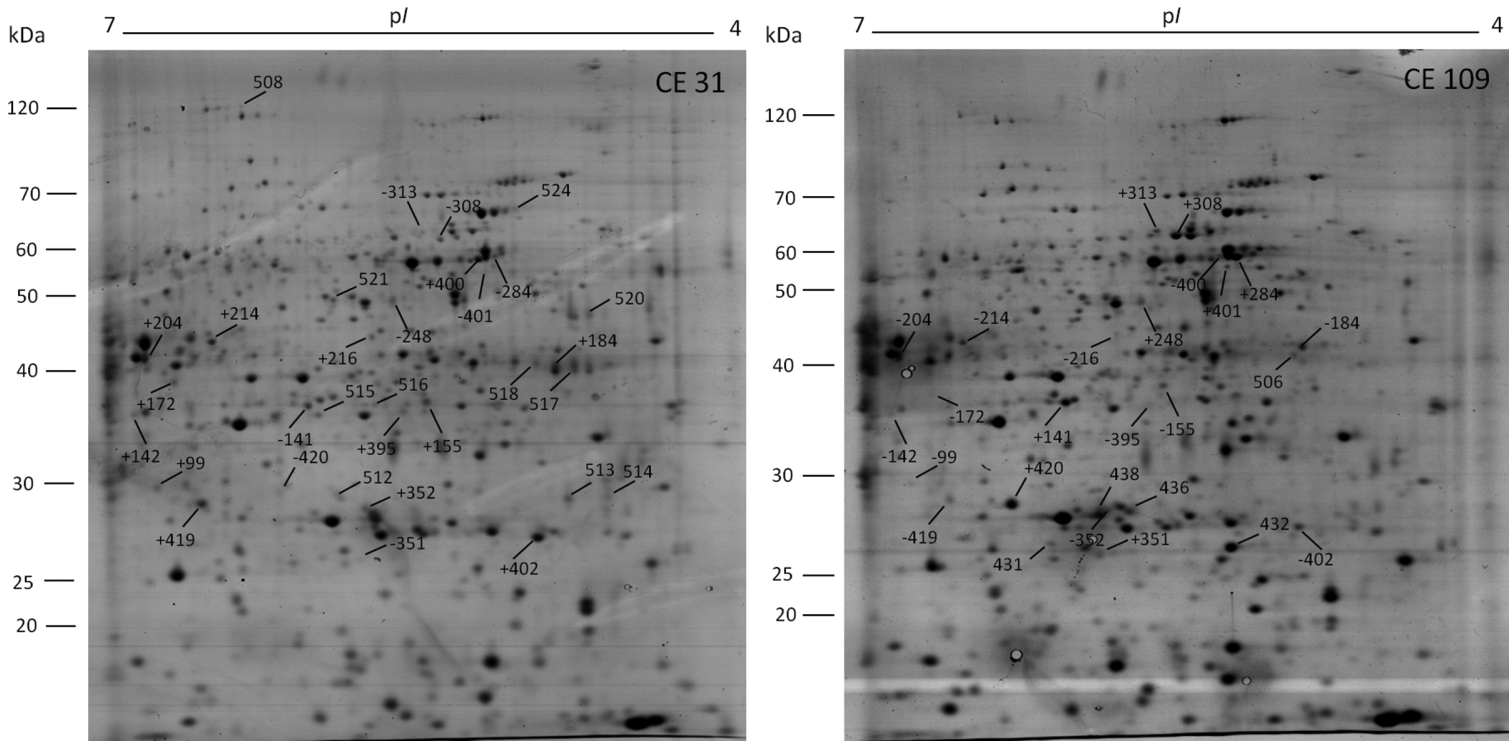

Figure 1. 2-DE maps of CE 31 and CE 109 cultivars. The symbols + and - indicate increased and decreased proteins, respectively, in response to $M$. incognita. Numbers with no symbols indicate unique proteins.

One of the major challenges in plant-nematode interaction studies is to know how host proteins interact with pathogen effectors and which are the first signaling events triggered upon the recognition of the nematode by the plant that lead to resistance. Therefore, we have focused our analysis in the early stages of nematode infection (3-9 DAI). As a followup study of the proteomic analysis, we have further investigated the transcription profile of selected proteins showing increased expression in the resistant cultivar. Studies involving gene expression analysis of cowpea by qRT-PCR are limited and hence there is a lack of reliable reference genes to normalize the expression quantification in the genus Vigna. The two genes used herein as reference (ACT and GAPDH) showed stable expression levels in cowpea roots along the time-course assay in both challenged and control plants and, therefore, were validated as a good combination of reference genes for the pathosystem cowpea/nematode.

Below, we present a comprehensive analysis of the proteome data and the expression profiles of the corresponding genes, correlating the primary functions of the identified proteins to nematode infection response in an attempt to understand their role during the plant-nematode interaction.

\subsection{Proteins increased in the highly resistant cultivar CE 31}

Several studies on expression changes in the host plant upon RKN infection have shown the involvement of hormones in the regulation of cell growth and stress tolerance by modulation of ROS levels [30-32]. Although the occurrence of oxidative stress upon nematode infection is a known phenomenon, the identification of genes and proteins being modulated during this process is still an important field of investigation.
Moreover, incompatible interactions are rarely studied and to date only eight nematode resistance genes have been isolated and shown to confer resistance to cyst or RK nematodes [33]. Therefore, the comparison of contrasting cultivars in response to $M$. incognita can provide unique contributions for a better understanding of nematode resistance processes involving oxidative stress response.

At the first stages of cowpea infection by M. incognita, the levels of several proteins associated to oxidative stress response were increased in CE 31, including a multicatalytic endopeptidase complex (proteasome), hydroxyacid oxidase, gamma-type carbonic anhydrase family protein, ferredoxinNADP reductase isozyme 2 , and glutathione $S$-transferase (Fig. 2; Table 1). All these proteins, although associated to ROS scavenging, are also involved in other important processes for plant defense. The multicatalytic endopeptidase complex (proteasome) protein identified in this study, for example, is part of the plant $26 \mathrm{~S}$ proteasome, which is an essential component of the Ubiquitin/26S proteasome degradation system (UPS). UPS plays a crucial role in the degradation of short-lived regulatory proteins and in host immune responses triggered by pathogen attack [34]. It has also been shown that the proteasome is responsible for the degradation of oxidantdamaged proteins $[35,36]$ and the control of plant development and responses to stress [34]. The activation of UPS is an important defense mechanism and has been reported in other plant-pathogen interactions [37,38]. Additionally, the expression behavior of cowpea proteasome-encoding genes in response to $M$. incognita inoculation obtained by qRT-PCR (Fig. 3) was in complete accordance with the proteome analysis, showing a very similar profile with enhanced expression approximately sevenfold from 3 to 6 DAI and keeping up these levels until 9 DAI. 
Table 1. Differentially expressed proteins from CE 31 and CE 109 infected with $M$. incognita, analyzed by MS

\begin{tabular}{|c|c|c|c|c|}
\hline $\begin{array}{l}\text { Spot } \\
\text { number }\end{array}$ & Protein identification ${ }^{a)}$ & $\begin{array}{l}\text { Acession } \\
(\mathrm{NCBlnr})^{\mathrm{b})}\end{array}$ & Organism & $\begin{array}{l}\text { Fold } \\
\text { change in } \\
\text { CE } 31 \\
\text { related to } \\
\text { CE } 109^{c)}\end{array}$ \\
\hline 99 & Gama carbonic anhydrase-like (F18014.34) & gi|8778427 & Arabidopsis thaliana & +2.31 \\
\hline 141 & $\begin{array}{l}\text { Cinnamyl-alcohol dehydrogenase family protein } \\
\text { (CPRD } 14 \text { protein) }\end{array}$ & gi|1854445 & Vigna unguiculata & -1.55 \\
\hline 142 & UCRVU07_CCNP15642_b1 (Annexin) & $g i \mid 190493106^{d)}$ & Vigna unguiculata & +4.84 \\
\hline 155 & UCRVU07_CCNP3199_b1 (Fructokinase) & gi|190468481d) & Vigna unguiculata & +9.62 \\
\hline 172 & UCRVU05_CCNN18825_b1 (Ferredoxin) & $\mathrm{gi} \mid 190455501^{\mathrm{d})}$ & Phaseolus vulgaris & +9.40 \\
\hline 184 & Patatin-17-like & $\begin{array}{l}\text { gi } \mid 356520766 \\
\text { gi } \mid 565342133\end{array}$ & $\begin{array}{l}\text { Glycine max } \\
\text { Solanum tuberosum }\end{array}$ & +4.28 \\
\hline 204 & Glyceraldehyde-3-phosphate dehydrogenase & $\begin{array}{l}\text { gi } \mid 543176466 \\
\text { gi } \mid 62816190\end{array}$ & $\begin{array}{l}\text { Phaseolus vulgaris } \\
\text { Lupinus albus }\end{array}$ & +2.66 \\
\hline 214 & $\begin{array}{l}\text { Hypothetical protein EUTSA_v10028651mg } \\
\text { (Elongation factor Tu) }\end{array}$ & gi|567161651 & Eutrema salsugineum & +1.29 \\
\hline 216 & Isovaleryl-CoA-dehydrogenase precursor & gi|5596622 & Arabidopsis thaliana & +1.96 \\
\hline 248 & S-Adenosylmethionine synthase & $\begin{array}{l}\text { gi|1709006 } \\
\text { gi|558695842 } \\
\text { gi|543176428 } \\
\text { gi|558695842 }\end{array}$ & $\begin{array}{l}\text { Actinidia chinensis } \\
\text { Phaseolus vulgaris } \\
\text { Phaseolus vulgaris } \\
\text { Phaseolus vulgaris }\end{array}$ & -1.42 \\
\hline 284 & $\begin{array}{l}\text { MOPEW79TF (ribulose 1.5-bisphosphate } \\
\text { carboxylase/oxygenase large subunit) }\end{array}$ & $\mathrm{gi} \mid 182658412^{\mathrm{d})}$ & Vigna unguiculata & -2.70 \\
\hline 308 & $\begin{array}{l}\text { MOPF213TF (pyruvate dehydrogenase E1 component } \\
\text { beta subunit) }\end{array}$ & gi|182660042 ${ }^{\mathrm{d})}$ & Vigna unguiculata & -3.32 \\
\hline 313 & $\begin{array}{l}\text { Hypothetical protein PHAVU_010G163900g (vacuolar } \\
\text { H+-ATPase) Protein SET-5, isoform d }\end{array}$ & $\begin{array}{l}\text { gi } \mid 593267358 \\
\text { gi } \mid 453232574\end{array}$ & $\begin{array}{l}\text { Phaseolus vulgaris } \\
\text { Caenorhabditis } \\
\text { elegans }\end{array}$ & -2.19 \\
\hline 351 & $\begin{array}{l}\text { Hypothetical protein PHAVU_011G084400g } \\
\text { (Glyoxalase_I) }\end{array}$ & gi|593194743 & Phaseolus vulgaris & -4.31 \\
\hline 352 & $\begin{array}{l}\text { Multicatalytic endopeptidase complex. proteasome } \\
\text { component (alpha subunit) Protein PAS-1 }\end{array}$ & $\begin{array}{l}\text { gi|} 2511588 \\
\text { gi|} 17562788\end{array}$ & $\begin{array}{l}\text { Arabidopsis thaliana } \\
\text { Caenorhabditis } \\
\quad \text { elegans }\end{array}$ & +7.63 \\
\hline 395 & $\begin{array}{l}\text { UCRVU05_CCNN15860_b1 (F0F1 ATP synthase } \\
\text { subunit beta) }\end{array}$ & gi|190451397d) & Vigna unguiculata & +3.20 \\
\hline 400 & $\begin{array}{l}\text { Hypothetical protein PHAVU_007G034800g (ATP } \\
\text { synthase subunit beta) }\end{array}$ & gi|593627323 & Phaseolus vulgaris & +7.03 \\
\hline 401 & $\begin{array}{l}\text { UCRVU09_CCNT13871_b1 (ribulose 1.5-bisphosphate } \\
\text { carboxylase/oxygenase large subunit) }\end{array}$ & gi| $190556563^{d)}$ & Vigna unguiculata & -5.28 \\
\hline 402 & $\begin{array}{l}\text { Glutathione transport system permease protein } \\
\text { GsiC-like (partial) }\end{array}$ & gi|449468157 & Cucumis sativus & +5.59 \\
\hline 419 & $\begin{array}{l}\text { Hypothetical protein PHAVU_010G011300g (NAD (P) } \\
\text { binding site) }\end{array}$ & gi|593263658 & Phaseolus vulgaris & +2.81 \\
\hline 420 & UCRVU08_CCNS9838_b1 (Chaperonin 10) & $g i \mid 190521803^{d)}$ & Phaseolus vulgaris & -6.38 \\
\hline 431 & $\begin{array}{l}\text { Glutathione S-transferase F9-like Hypothetical protein } \\
\text { PHAVU_006G020800g (glutathione S-transferase) }\end{array}$ & $\begin{array}{l}\text { gi } \mid 356526968 \\
\text { gi } \mid 593691257\end{array}$ & $\begin{array}{l}\text { Glycine max } \\
\text { Phaseolus vulgaris }\end{array}$ & $\begin{array}{l}\text { Unique to } \\
\text { CE } 109\end{array}$ \\
\hline 432 & Chalcone isomerase (fragment) & gi|81864 & Phaseolus vulgaris & $\begin{array}{l}\text { Unique to } \\
\text { CE } 109\end{array}$ \\
\hline 436 & $\begin{array}{l}\text { Unknown (proteasome-subunit alpha) Hypothetical } \\
\text { protein PHAVU_004G073800g (proteasome subunit } \\
\text { alpha) Protein LNP-1 }\end{array}$ & $\begin{array}{l}\text { gi|} 255648341 \\
\text { gi|} 593702733 \\
\text { gi|} 17550174\end{array}$ & $\begin{array}{l}\text { Glycine max } \\
\text { Phaseolus vulgaris } \\
\text { Caenorhabditis } \\
\quad \text { elegans }\end{array}$ & $\begin{array}{l}\text { Unique to } \\
\text { CE } 109\end{array}$ \\
\hline 438 & $\begin{array}{l}\text { UCRVU08_CCNS4917_b1 (cytosolic ascorbate } \\
\text { peroxidase) }\end{array}$ & gi|190516707d) & Vigna unguiculata & $\begin{array}{l}\text { Unique to } \\
\text { CE } 109\end{array}$ \\
\hline 506 & $\begin{array}{l}\text { Hypothetical protein PHAVU_011G053800g } \\
\text { (Fructokinase) Fructokinase }\end{array}$ & $\begin{array}{l}\text { gi } \mid 593154227 \\
\text { gi } \mid 585973\end{array}$ & $\begin{array}{l}\text { Phaseolus vulgaris } \\
\text { Solanum tuberosum }\end{array}$ & $\begin{array}{l}\text { Unique to } \\
\text { CE } 109\end{array}$ \\
\hline 508 & $\begin{array}{l}\text { UCRVU05_CCNN15860_b1 (F0F1 ATP synthase } \\
\text { subunit beta) }\end{array}$ & gi $\mid 190451397^{d)}$ & Vigna unguiculata & $\begin{array}{l}\text { Unique to } \\
\text { CE } 31\end{array}$ \\
\hline 512 & Unknown (chorismate mutase) & gi|255640032 & Glycine max & $\begin{array}{l}\text { Unique to } \\
\text { CE } 31\end{array}$ \\
\hline
\end{tabular}


Table 1. Continued

\begin{tabular}{|c|c|c|c|c|}
\hline $\begin{array}{l}\text { Spot } \\
\text { number }\end{array}$ & Protein identification ${ }^{a)}$ & $\begin{array}{l}\text { Acession } \\
\left.\left(^{(N C B I n r}\right)^{b}\right)\end{array}$ & Organism & $\begin{array}{l}\text { Fold } \\
\text { change in } \\
\text { CE } 31 \\
\text { related to } \\
\text { CE } 109^{c)}\end{array}$ \\
\hline 513 & UCRVU04_CCNI1299_b1 (Glutathione S-transferase) & gi|190463341d) & Phaseolus vulgaris & $\begin{array}{l}\text { Unique to } \\
\text { CE } 31\end{array}$ \\
\hline 514 & $\begin{array}{l}\text { UCRVU09_CCNT13871_b1(ribulose 1.5-bisphosphate } \\
\text { carboxylase/oxygenase large subunit) }\end{array}$ & gi| $190556563^{d)}$ & Vigna unguiculata & $\begin{array}{l}\text { Unique to } \\
\text { CE } 31\end{array}$ \\
\hline 515 & UCRVU04_CCNI1065_b1 (protein disulfide isomerase) & gi| $190415885^{d)}$ & Vigna unguiculata & $\begin{array}{l}\text { Unique to } \\
\text { CE } 31\end{array}$ \\
\hline 516 & Nitrile-specifier protein 5 & gi|356525790 & Glycine max & $\begin{array}{l}\text { Unique to } \\
\text { CE } 31\end{array}$ \\
\hline 517 & Spermidine synthase & gi|6094335 & Coffea arabica & $\begin{array}{l}\text { Unique to } \\
\text { CE } 31\end{array}$ \\
\hline 518 & $\begin{array}{l}\text { Os11g0652100/hypothetical protein (putative NB-ARC } \\
\text { domain-containing protein) }\end{array}$ & gi|115486473 & Oryza sativa Japonica & $\begin{array}{l}\text { Unique to } \\
\text { CE } 31\end{array}$ \\
\hline 520 & Hydroxyacid oxidase 1 Protein SWSN-1, isoform a & $\begin{array}{l}\text { gi|226500726 } \\
\text { gi|392923158 }\end{array}$ & $\begin{array}{l}\text { Zea mays } \\
\text { Caenorhabditis } \\
\quad \text { elegans }\end{array}$ & $\begin{array}{l}\text { Unique to } \\
\text { CE } 31\end{array}$ \\
\hline 521 & $\begin{array}{l}\text { 6-Phosphogluconate dehydrogenase. } \\
\text { decarboxylating-like }\end{array}$ & gi|449447452 & Cucumis sativus & $\begin{array}{l}\text { Unique to } \\
\text { CE } 31\end{array}$ \\
\hline 524 & $\begin{array}{l}\text { UCRVU08_CCNS1576_b1 (F0F1 ATP synthase subunit } \\
\text { beta) }\end{array}$ & gi| $190511123^{d)}$ & Vigna unguiculata & $\begin{array}{l}\text { Unique to } \\
\text { CE } 31\end{array}$ \\
\hline
\end{tabular}

a) Protein identification by MASCOT. Using database of plant ESTs.

b) More than one accession cited indicates different hits for peptides identified from the same protein.

c) The "+" and "-" signals indicate increased and decreased proteins, respectively.

d) Protein Identification by LC-MS, using ESTs database (Vigna unguiculata).

Proteins potentially involved in hypersensitive response (HR) were also identified in this study with increased expression in inoculated CE 31 (Fig. 2; Table 1), such as hydroxyacid oxidase (or glycolate oxidase), which is a peroxisomal enzyme that participates in the generation of ROS and is involved in the oxidative stress signal transduction cascade in response to pathogen attack [39]. It has been demonstrated that glycolate oxidase is an alternative source for the production of $\mathrm{H}_{2} \mathrm{O}_{2}$ and plays a main role in both gene-for-gene-mediated and nonhost resistance responses [40]. Similarly, aldo-keto reductase is also involved in ROS signaling network by detoxifying stress-associated reactive carbonyl products that mitigate the effects of ROS, preventing oxidative damage [41]. The qRTPCR expression profiles of hydroxyacid oxidase and aldo-keto reductase showed a gradual increase in transcript levels in the days subsequent to nematode infection (Fig. 3). Therefore, the induction of hydroxyacid oxidase and aldo-keto reductase in response to oxidative stress triggered by the RKN inoculation could be associated with the transition between defense responses and basic metabolism to restore homeostasis and return to normal metabolic conditions as a mechanism of resistance in CE 31 cultivar.

Another identified protein, possibly involved in HR, was a protein that belongs to the gamma-type carbonic anhydrase family (Table 1), formed by five enzymes displayed in the plant mitochondrial Complex I [42]. Carbonic anhydrase has been associated to resistance in the interaction between
Brassica carinata and the fungal pathogen Leptosphaeria maculans [43]. Moreover, it has been demonstrated that the silencing of this gene in tomato resulted in suppression of pto:avrpto-mediated HR [44]. In cowpea CE 31, carbonic anhydrase is positively regulated in response to nematode infection (Fig. 2) and could also be related to its resistance response.

Plants, when infected by nematodes, present loss of vigor, leaf chlorosis, general compromised development, among other symptoms. Consequently, the expression of the proteins involved in these processes is also affected (reviewed in [45]). In this study, we have identified proteins in CE 31 associated to plant growth and development that may have an important role in resistance, including spermidine synthase and nitrile-specifier protein 5, unique to CE 31 and patatin 17-like, increased in CE 31 (Table 1).

Hewezi et al. [46] showed that spermidine synthase 2 is a target of a cyst nematode effector that inhibits plant defense responses. It has also been reported that the overexpression of spermidine synthase induces the expression of stress-related genes, such as the transcriptional factor DREB, associated with increased tolerance to environmental stresses [47]. Cowpea spermidine synthase revealed to be unique in CE 31 and its transcript levels determined by qRT-PCR displayed a gradual increase in the days subsequent to nematode infection (Fig. 3), with a maximum level of gene expression (4.85-fold) at 9 DAI. 

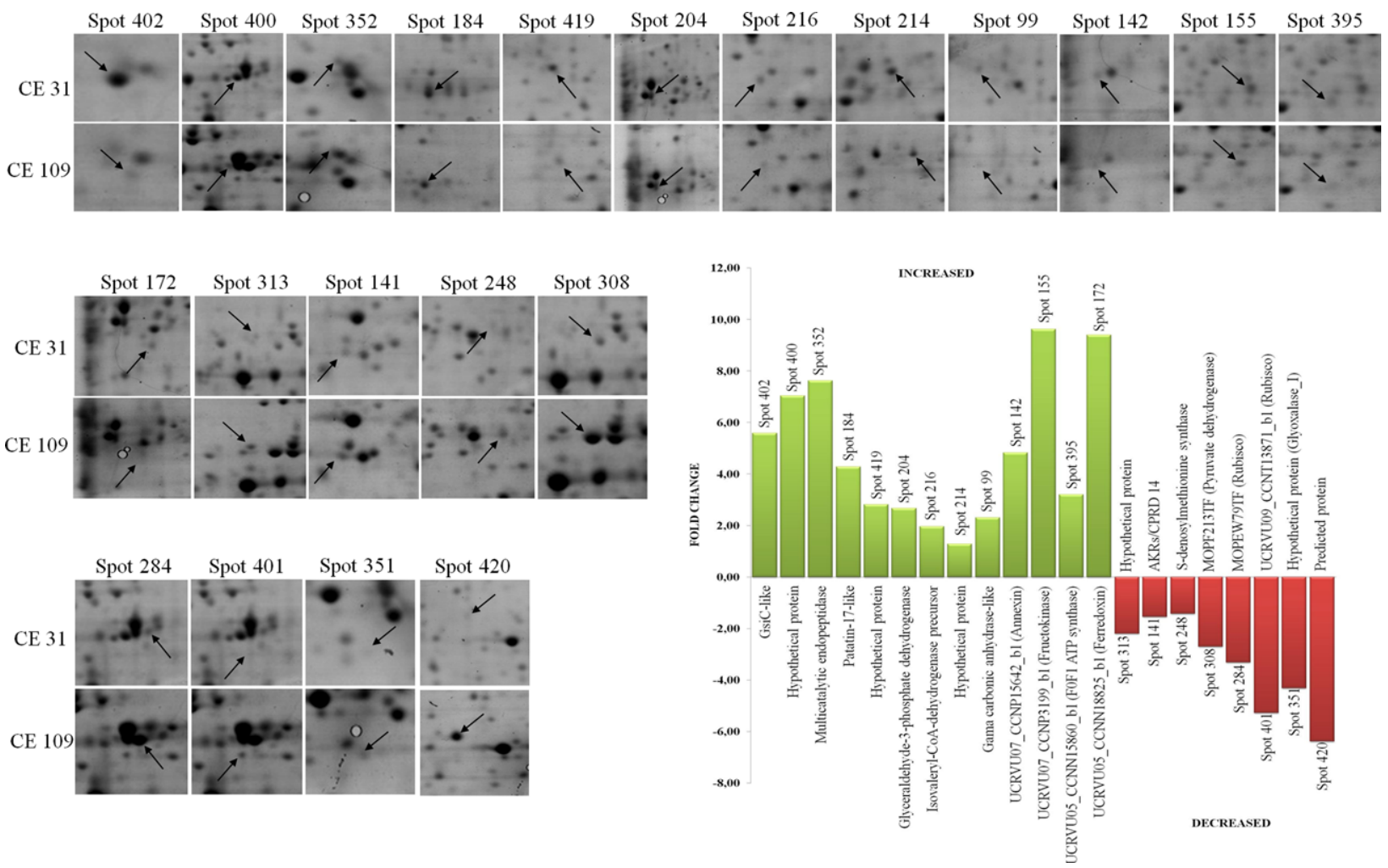

Figure 2. Overview of increased and decreased proteins in the highly resistant cowpea cultivar CE 31. Arrows indicate the protein spots identified. The graph represents the fold change of the differential expression of these proteins in CE 31 when compared to CE 109.

Nitrile specifier was another protein identified in CE 31, involved in resistance, which had not been yet reported in cowpea-nematode interaction studies. This protein is involved in the hydrolysis of glucosinolates, secondary metabolites present in Brassicaceae plants. It has been suggested that intact glucosinolates are biologically inactive, while the products of its degradation after hydrolysis may have multiple functions in the regulation of growth and plant defense [48]. Therefore, the identification of a nitrile-specifier protein in CE 31 may indicate activation of the plant secondary metabolite pathways as a defense mechanism against $M$. incognita. Notably, nitrile-specifier protein showed the highest transcriptional induction in response to the nematode infection in the qRT-PCR analysis, in particular at 9 DAI (26.52-fold; Fig. 3). Nitrile-specifier protein was here identified as unique in the highly resistant CE 31 cultivar (Table 1), which is in accordance with its strong gene expression induction at 9 DAI.

As nitrile-specifier protein, isopropylmalate dehydrogenase is also involved in the glucosinolate pathway and these proteins are probably under the control of the same regulatory system. Although not detected in our proteome analysis, isopropylmalate dehydrogenase transcripts showed a high induction in its expression (19.53-fold; Fig. 3) in response to the nematode infection. These results could indicate that the expression of nitrile-specifier protein and isopropylmalate dehydrogenase genes are simultaneously triggered by the nematode infection and lead to the activation of glucosinolate metabolism to circumvent pathogen attack.

Another protein increased in CE 31 was patatin (Fig. 2; Table 1), which is a storage glycoprotein that has lipid acyl hydrolase activity and is also associated with defense against plant pests [49, 50]. Camera et al. [51] showed that a patatinlike protein 2 is an important component of the plant defense machinery to combat the cucumber mosaic virus. Regarding the patatin transcripts, a modest increase was observed along the bioassay time course, beginning by a downregulation response to nematode attack at $3 \mathrm{DAI}$ and reaching a maximum level of expression at 9 DAI (Fig. 3). The results showed that both transcription and protein profiles of patatin were similar, however, the magnitude of fold change was smaller in the qRT-PCR analysis (from -1.67 to +2.22 ; Fig. 3 ) when compared to the proteome results $(+4.28$; Table 1$)$.

Interestingly, we also identified the resistance protein RPP13, which is a member of the NBS-LRR family of plant R-genes and confers resistance to the causal agent of downy mildew in A. thaliana [52]. This protein was unique to CE 31 and may play a crucial role in resistance. The transcription profile of RPP13 obtained by qRT-PCR revealed an increasing upregulation from 3 to 9 DAI. These results are compatible with its expected role in the initiation of a complex defense response to pathogen infection often leading to host immune response. 


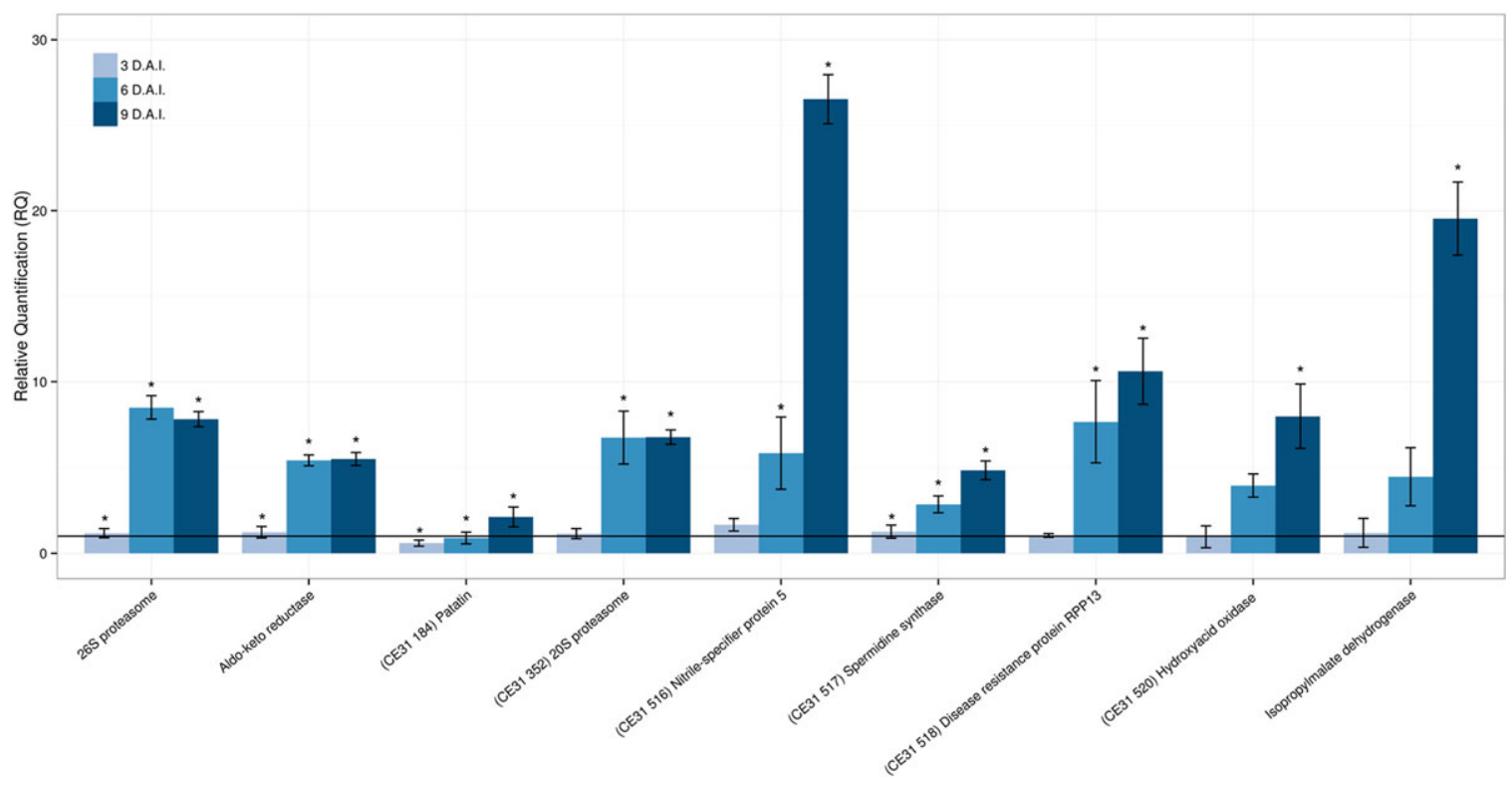

Figure 3. Relative quantification (RQ) of mRNA levels of nine candidate genes differentially expressed in cowpea roots challenged with $M$. incognita at 3, 6, and 9 days after inoculation (DAI), relative to day 0. Bars represent the standard error of the mean of two biological replicates for each sample and the horizontal line indicates $R Q=1.0$. Significantly $(p \leq 0.05)$ up- or downregulated genes are indicated by asterisk $(*)$.

Overall, the results obtained by proteome and transcriptome approaches give strong evidence that oxidative stress is part of the resistance mechanisms of CE 31 cultivar. Similar results were recently obtained by Oliveira et al. [18] using the same cultivar CE 31 in the comparison between M. incognita inoculated and noninoculated plants. These authors observed an increase in several oxidative stress proteins in inoculated plants such as superoxide dismutase and peroxidase. In the current study, we have identified additional processes implicated in plant resistance and programed cell death including ubiquitination and hydrolysis of glucosinolates, which may be part of the complex resistance mechanism of CE 31 cultivar to combat nematode infection.

\subsection{Proteins decreased in the highly resistant cultivar CE 31}

Some proteins showed a negative regulation after M. incognita inoculation in the highly resistant cultivar CE 31, such as the stress-related proteins glyoxalase and chaperonin 10 (Table 1 ). We also observed two differential protein spots with decreased expression in CE 31 (spot 284 and spot 401; Fig. 2; Table 1) corresponding to Rubisco large subunit (LSU). Despite the fact that the partial hydrolysis of Rubisco LSU has been associated to oxidative stress in barley chloroplasts [53], the expression of Rubisco subunit in roots is still intriguing. Reports have already described the presence of photosynthesisrelated genes/proteins in nonphotosynthetic tissues [54] however, additional studies need to be performed in order to further investigate the expression of Rubisco in cowpea roots. It is possible that the oxidative stress induced in the resistant response lead to the decreased intensity of LSU in CE 31. Another spot (514) identified as Rubisco LSU was unique to CE 31 (Fig. 1; Table 1); however, the molecular mass was lower than the theoretical mass $(27 \mathrm{kDa}$ instead of $52 \mathrm{kDa}$; Supporting Information Table 3), indicating some degradation or processing of this protein.

Some unique proteins were also identified in the slightly resistant cultivar CE 109 such as cytosolic ascorbate peroxidase (Fig. 1; Table 1). These results contrast those obtained by Oliveira et al. [18] that observed an increase in ascorbate peroxidase in CE 31 inoculated with $M$. incognita when compared to noninoculated plants. Contrasting results were also obtained for chalcone synthase, a key enzyme of the flavonoid/isoflavonoid biosynthesis pathway, which was also identified in this study as unique in CE 109. Oliveira et al. [18] again observed an increase in this protein in CE 31 inoculated with $M$. incognita. Different sampling points were analyzed in both studies (4 and 6 DAI vs. 3-9 DAI) and may have influenced the levels of these proteins, which seem to be highly variable and dependent on the infection process. It is possible that at 9 DAI these proteins are no longer needed to cope with $M$. incognita infection in CE 31, since other resistance processes are activated, such as ubiquitination and glucosinolate hydrolysis.

Two different protein spots, one unique to CE 31 and the other unique to CE 109, were identified as glutathione $S$-transferase, which is a major cellular detoxification enzyme and plays important roles in plant protection against biotic and abiotic stresses [55]. It is possible that these different spots represent isoforms or PTMs and their distinct 
expression may result in different responses to $M$. incognita infection.

Unlike the highly resistant cultivar CE 31, it seems that CE 109 showed a basal defense response by triggering the increase in general stress-related proteins such as peroxidase, glyoxalase, and chaperonin. In order to determine resistance, signaling processes of defense and the chain of events that occur in the host plants upon the pathogen perception must be immediate to allow the induction of early or long-lasting resistance mechanisms, which may not have occurred in CE 109. Flavonoids represent a class of secondary metabolites with diverse functions in plant development and response to stresses, including wounding and pathogen attack [56]. It seems that oxidative stress, as well as stress and wounding response are prevalent in CE 109 and that more sophisticated resistance mechanisms, such as those presented by CE 31, need to be activated in order to cope with $M$. incognita infection.

\subsection{Prediction of $M$. incognita-cowpea interactome}

The investigation of the interactions among proteins potentially involved in the response to nematode infection can provide new insights for pathogen control. As cowpea genetic and genomic resources are still limited, the gold-standard gene product annotation of the model plant $A$. thaliana was used to predict the interactome of the differentially expressed proteins identified between the two cowpea cultivars (Fig. 4; Supporting Information Table 4). Out of the 37 proteins identified in this study, 35 showed homology to $A$. thaliana proteins. Two proteins were identified in multiple spots (spots 284, 401, 514 and 395, 400, 508; Table 1 and Supporting Information Table 4) and hence were considered only once. Two proteins did not show orthologs in A. thaliana and were therefore not included in the interactome analysis. The interactome was therefore performed with 31 different proteins: 20 for CE 31 and 12 for CE 109.

The results obtained using the String program showed that for the highly resistant CE 31 cultivar, ten out of 20 proteins interact with at least one protein (Fig. 4) based on evidence from co-expression, experiments, and text-mining information. On the other hand, for the slightly resistant cultivar CE 109 , only a few direct interaction between differentially or uniquely expressed proteins was predicted (Fig. 4). However, when up to 20 protein interactions were added, it was possible to visualize two protein interaction clusters for CE 31 and three for CE 109 (Fig. 4). In order to identify possible metabolic pathways, a Kegg enrichment analysis was performed and revealed that proteasome (Supporting Information Fig. 1) and oxidative phosphorylation pathways could be activated in both cultivars while flavonoid biosynthesis pathway (Supporting Information Fig. 2) could be activated only in CE 109. As evidenced here in protein and gene expression analyses, these pathways seem to be important processes in response to $M$. incognita attack in cowpea cultivars.
An additional network based on mRNA co-expression evidences was built using GeneMania (Fig. 4), which revealed a higher number of protein co-expression when compared to the results obtained using the String program. The GeneMania results suggest that most of the differentially expressed proteins (14 out of 20 proteins in CE 31 and nine out of 12 in CE 109) co-express with at least one product during biotic stresses. Although the results are based on a predictive interaction, the data obtained show that most proteins identified in the present study are part of a network activated during plant-pest interaction. At present, experimental evidence on protein-protein interaction is highly limited, even in the well-studied A. thaliana [57], which hinders a more profound comprehension on the interactome. Further studies need to be conducted in order to confirm the interactions predicted for cowpea upon $M$. incognita infection.

Based on gene ontology classification, noteworthy is the fact that ten of the 31 differentially expressed protein spots (Supporting Information Table 4) were associated with response to cadmium ion (GO:0046686), most of which (seven proteins) were increased or unique in CE 31 (Fig 4, redcolored nodes). This GO term was by far the most common term among the homologous proteins. Plants can be classified as hyperaccumulators and nonhyperaccumulators in accordance with the unusual metal element concentration in their aboveground tissues. There are evidences suggesting that hyperaccumulated ions could confer tolerance to abiotic stress, as drought, and resistance to biotic stress, as nematodes. The "defense hypothesis," defined by Boyd and Martens [58] proposes, on a molecular basis, that accumulated ions could induce common or complementary pathways to enhance the plant defense response against insect pests and pathogens. The crosstalk involving metal accumulation/homeostasis and biotic stresses signaling pathways was reviewed by Poschenrieder et al. [59]. Few studies have associated the presence of metals and plant resistance to fungus or bacteria, but not yet to nematodes [60-62]. There is no evidence that $V$. unguiculata is a cadmium hyperaccumulator, but recent studies indicated that this legume can be considered as a phytoremediator plant in zinc contaminant soils [63].

\section{Concluding remarks}

In this study, we have investigated the proteins expressed during early stages of $M$. incognita infection in highly and slightly resistant cowpea cultivars and have found several proteins differentially expressed. Regarding the global pattern of protein expression upon $M$. incognita infection, we observed that the majority of the 37 identified proteins are unique (11) or increased (13) in CE 31 (Fig. 2 and Table 1). These results seem to be in contrast with previous studies that reported a trend toward a downregulation of genes and partial suppression of typical defense response in incompatible cowpea-RKN interaction when compared to the compatible 
A
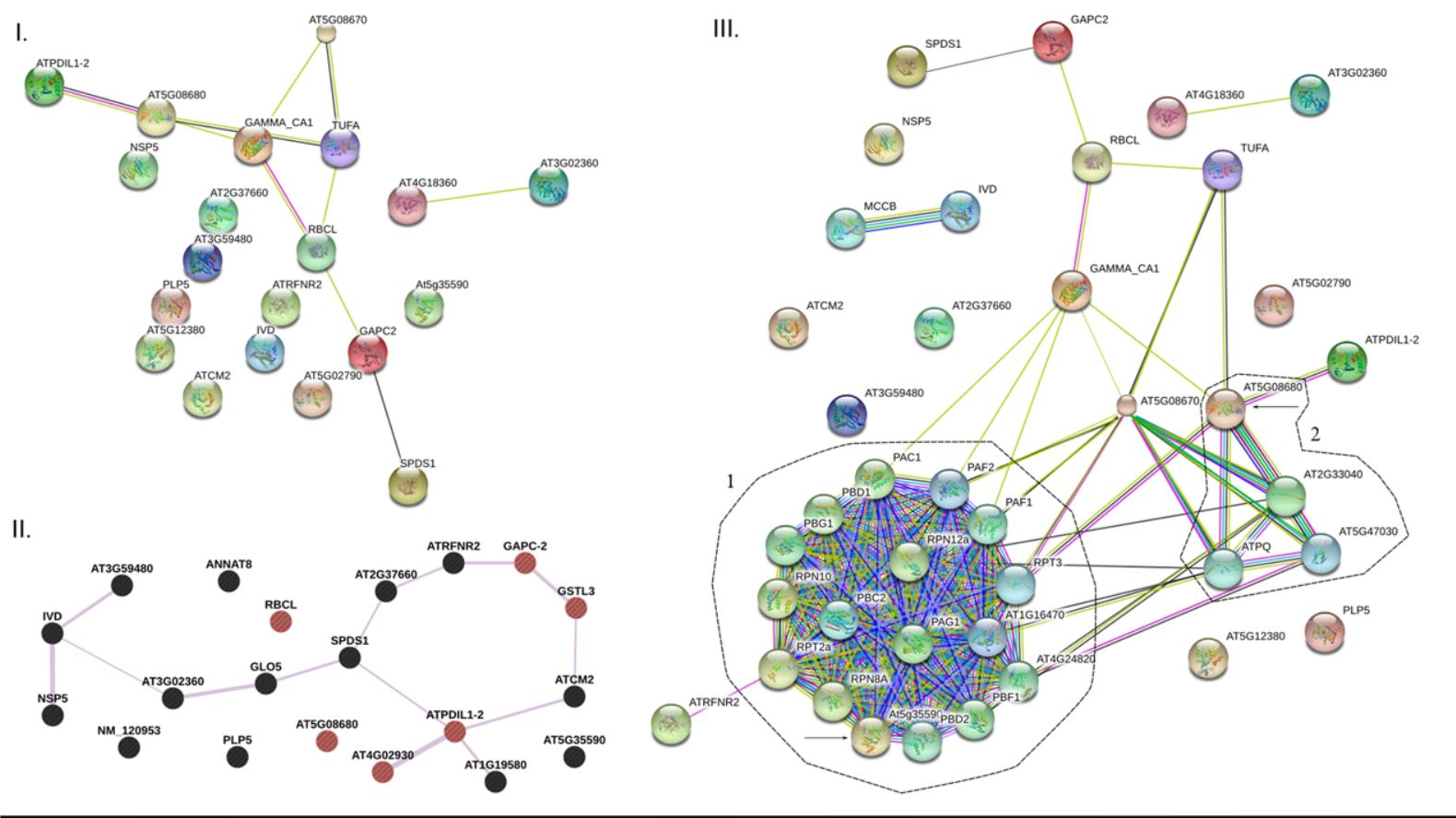

II.
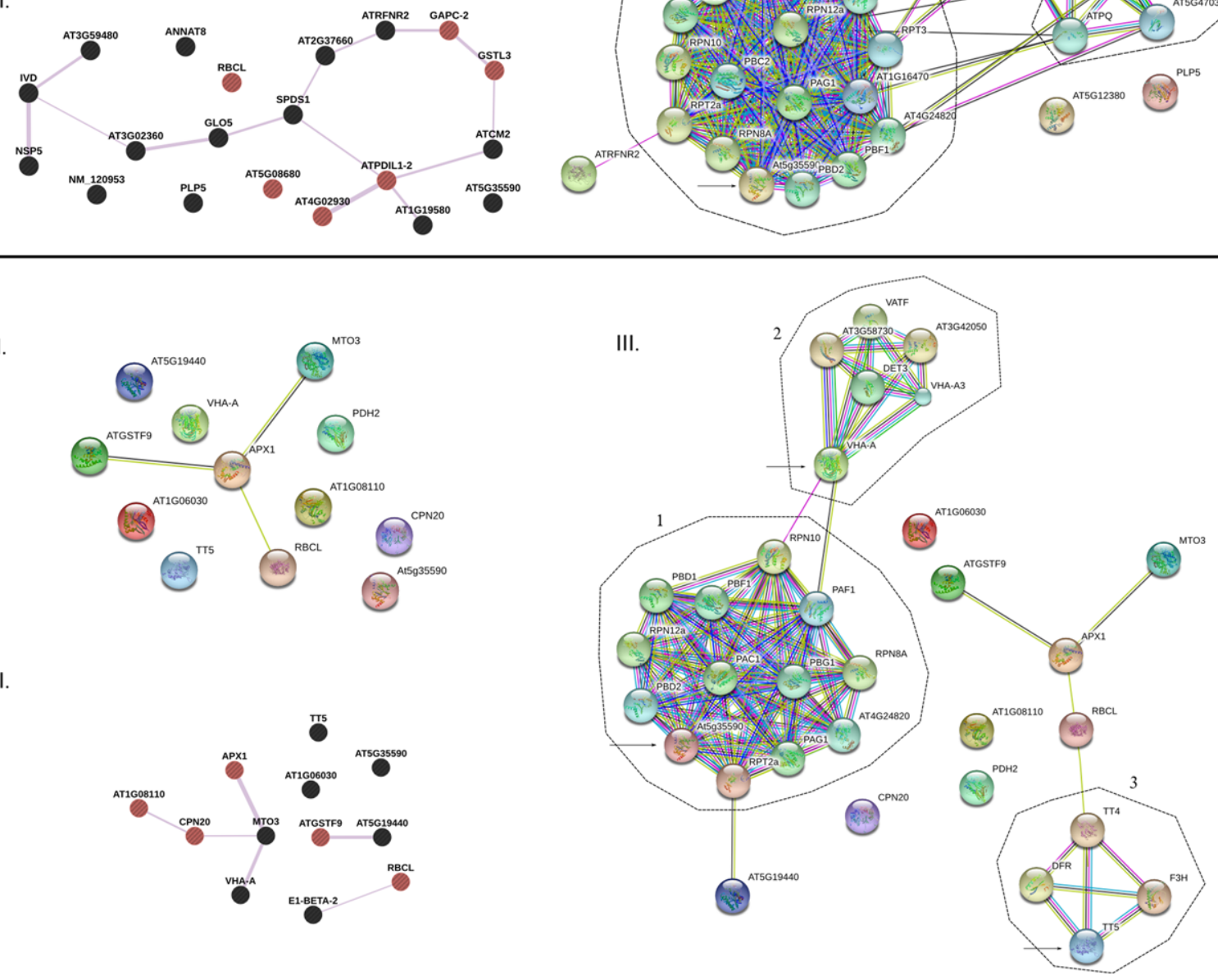

Figure 4. Interactome prediction using $A$. thaliana homologous genes. (A) Highly resistant CE 31 cultivar. (B) Slightly resistant CE 109 cultivar. Networks showing interactions among proteins belonging to our dataset were predicted using String v. 9.1 (I and III) and GeneMania (II). The type of evidence is as follows: dark green line-neighborhood; red line-gene fusion; dark blue line-co-occurrence; black lineco-expression; pink line-experiments; light blue-databases; light green-text mining. Dotted lines indicate predicted Kegg pathways: 1 -proteasome; 2-oxidative phosphorylation; 3-flavonoid biosynthesis. Arrows indicate proteins belonging to our dataset that participate in the predicted Kegg pathways. In figures All and Bll, proteins associated with response to cadmium ion (GO:0046686) are indicated in red. 
interaction [64]. However, the majority of these studies analyzed differential expression profiles only at the transcript level. Therefore, one of the main advantages of proteomic global profiling is that the final product of gene expression is detected, showing that the protein is indeed produced to play its biological role. In this study, we identified several proteins increased or unique to highly resistant CE 31 that could be involved in nematode defense and resistance mechanisms. Interestingly, qRT-PCR analyses showed that the transcripts and proteins had a very similar upregulation trend in CE 31, including the LRR resistance gene. These data are in accordance with previous reports showing that upregulated transcripts usually result in increased abundance of proteins [65]. For example, the majority of the analyzed transcripts corresponding to upregulated proteins showed basal gene expression levels at the beginning of nematode infection (3 DAI) followed by enhanced transcription levels as nematode infection progressed (6-9 DAI). As observed in the proteome and transcriptome analysis, the interactome prediction also revealed that oxidative stress is crucial for resistance, since oxidative phosphorylation was affected by nematode infection. Additionally, the interactome prediction revealed a potential role of several proteins in metal resistance, which might also be associated to resistance to biotic stresses. Further studies need to be performed in order to confirm this hypothesis.

Overall, this study showed that each approach used (proteomics, relative quantification of transcripts, and interactome predictions) provided additional contributions to the understanding of the cowpea-nematode interaction. Taken together, these results indicate that some proteins with a putative role in RKN resistance (such as nitrile-specifier protein, RPP13, and spermidine synthase) showing similar transcription and protein expression behavior could be good candidates for engineering nematode resistance in agriculturally important crops. It seems that oxidative stress, ubiquitination, and glucosinolate degradation are part of cowpea CE 31 resistance mechanisms in response to nematode infection.

This work was sponsored by Embrapa, Ministério da Ciência e Tecnologia - MCT and Conselho Nacional de Desenvolvimento Científico e Tecnológico - CNPq. We thank CNPq for providing a scholarship to L.S.T.C. and a fellowship to A.M. We acknowledge the Laboratory of Mass Spectrometry of Embrapa Recursos Genéticos e Biotecnologia for the support in the mass spectrometry analysis.

The authors have declared no conflict of interest.

\section{References}

[1] Siddhuraju, P., Becker, K., The antioxidant and free radical scavenging activities of processed cowpea (Vigna unguiculata (L.) Walp.) seed extracts. Food Chem. 2007, 101, 10-19.

[2] Silveira, J. A. G. d., Costa, R. C. L. d., Oliveira, J. T. A., Drought-induced effects and recovery of nitrate assimila- tion and nodule activity in cowpea plants inoculated with bradyrhizobium spp. under moderate nitrate level. Braz. J. Microbiol. 2001, 32, 187-194.

[3] Clark, A. (Ed.), Managing Cover Crops Profitably 3rd ed. Sustainable Agriculture Network, Beltsville, MD 2007.

[4] Adegbite, A., Amusa, N., The major economic field diseases of cowpea in the humid agro-ecologies of South-western Nigeria. Afr. J. Biotechnol. 2008, 7, 47064712.

[5] Abad, P., Favery, B., Rosso, M.-N., Castagnone-Sereno, P., Root-knot nematode parasitism and host response: molecular basis of a sophisticated interaction. Mol. Plant Pathol. 2003, 4, 217-224.

[6] Trudgill, D. L., Blok, V. C., Apomictic, polyphagous rootknot nematodes: exceptionally successful and damaging biotrophic root pathogens. Ann. Rev. Phytopathol. 2001, 39, 53-77.

[7] Djian-Caporalino, C., Pijarowski, L., Fazari, A., Samson, M. et al., High-resolution genetic mapping of the pepper (Capsicum annuum L.) resistance loci Me3 and Me4 conferring heat-stable resistance to root-knot nematodes (Meloidogyne spp.). Theor. Appl. Genet. 2001, 103, 592-600.

[8] Fuller, V. L., Lilley, C. J., Urwin, P. E., Nematode resistance. New Phytol. 2008, 180, 27-44.

[9] Milligan, S. B., Bodeau, J., Yaghoobi, J., Kaloshian, I. et al., The root knot nematode resistance gene Mi from tomato is a member of the leucine zipper, nucleotide binding, leucinerich repeat family of plant genes. Plant Cell Online 1998, 10, 1307-1319.

[10] Fery, R. L., Dukes, P. D., Inheritance of root-knot nematode resistance in cowpea (Vigna unguiculata [L.] Walp.). J. Am. Soc. Hortic. Sci. 1980, 105, 671-674.

[11] Ehlers, J. D., Matthews, W. C., Hall, A. E., Roberts P. A., in: Fatokun, C. A., Tarawali, S. A., Singh, B. B., Kormawa, P. M., Tamò, M. (Eds.), Challenges and opportunities for enhancing sustainable cowpea production. Proceedings of the World Cowpea Conference III Held at the International Institute of Tropical Agriculture (IITA). Nigeria, Ibadan 2002, pp. 41-51.

[12] Gheysen, G., Mitchum, M., in: Berg, R. H., Taylor, C. (Eds.), Cell Biology of Plant Nematode Parasitism, Springer, Berlin Heidelberg 2009, pp. 45-81.

[13] Caillaud, M.-C., Dubreuil, G., Quentin, M., Perfus-Barbeoch, L. et al., Root-knot nematodes manipulate plant cell functions during a compatible interaction. J. Plant Physiol. 2008, $165,104-113$.

[14] Li, Y., Fester, T., Taylor, C., in: Berg, R. H., Taylor, C. (Eds.), Cell Biology of Plant Nematode Parasitism, Springer, Berlin Heidelberg 2009, pp. 189-220.

[15] Mehta, A., Brasileiro, A. C. M., Souza, D. S. L., Romano, E. et al., Plant-pathogen interactions: what is proteomics telling us? FEBS J. 2008, 275, 3731-3746.

[16] Oliveira, J. T. A., Andrade, N. C., Martins-Miranda, A. S., Soares, A. A. et al., Differential expression of antioxidant enzymes and PR-proteins in compatible and incompatible interactions of cowpea (Vigna unguiculata) and the root-knot nematode Meloidogyne incognita. Plant Physiol. Biochem. 2012, 51, 145-152. 
[17] Hussey, R. S., B. K., A comparison of methods of collecting inocula of Meloidogyne spp., including a new technique. Plant Dis. Rep. 1973, 57, 1025-1028.

[18] Oliveira, J., Araujo-Filho, J., Grangeiro, T., Gondim, D. et al., Enhanced synthesis of antioxidant enzymes, defense proteins and leghemoglobin in rhizobium-free cowpea roots after challenging with Meloydogine incognita. Proteomes 2014, 2, 527-549.

[19] Franco, O. L., Pereira, J. L., Costa, P. H. A., Rocha, T. L. et al., Methodological evaluation of 2-DE to study root proteomics during nematode infection in cotton and coffee plants. Prep. Biochem. Biotechnol. 2010, 40, 152-163.

[20] Ma, B., Zhang, K., Hendrie, C., Liang, C. et al., PEAKS: powerful software for peptide de novo sequencing by tandem mass spectrometry. Rapid Commun. Mass Spectrom. 2003, $17,2337-2342$.

[21] Cox, J., Mann, M., MaxQuant enables high peptide identification rates, individualized p.p.b.-range mass accuracies and proteome-wide protein quantification. Nat. Biotech. 2008, 26, 1367-1372.

[22] Untergasser, A., Nijveen, H., Rao, X., Bisseling, T. et al., Primer3Plus, an enhanced web interface to Primer3. Nucleic Acids Res. 2007, 35, W71-W74.

[23] Morgante, C. V., Brasileiro, A. C. M., Roberts, P. A., Guimaraes, L. A. et al., A survey of genes involved in Arachis stenosperma resistance to Meloidogyne arenaria race 1. Funct. Plant Biol. 2013, 40, 1298-1309.

[24] Zhao, S., Fernald, R. D., Comprehensive algorithm for quantitative real-time polymerase chain reaction. J. Comput. Biol. 2005, 12, 1047-1064.

[25] Lin, C.-H., Peng, P.-H., Ko, C.-Y., Markhart, A. H., Lin, T.-Y., Characterization of a novel Y2K-type dehydrin VrDhn1 from Vigna radiata. Plant Cell Physiol. 2012, 53, 930-942.

[26] Pfaffl, M. W., Horgan, G. W., Dempfle, L., Relative expression software tool (REST) for group-wise comparison and statistical analysis of relative expression results in real-time PCR. Nucleic Acids Res. 2002, 30, e36.

[27] Warde-Farley, D., Donaldson, S. L., Comes, O., Zuberi, K. et al., The GeneMANIA prediction server: biological network integration for gene prioritization and predicting gene function. Nucleic Acids Res. 2010, 38, W214-W220.

[28] Escobar, C., Brown, S., Mitchum, M., in: Jones, J., Gheysen, G., Fenoll, C. (Eds.), Genomics and Molecular Genetics of Plant-Nematode Interactions, Springer, the Netherlands 2011, pp. 157-173.

[29] Sasser, J. N., Carter, C. C., Hartman, K. M., Standardization of Host Suitability Studies and Reporting of Resistance to Root-knot Nematodes, Department of Plant Pathology, North Carolina State University 1984.

[30] Fuller, V. L., Lilley, C. J., Atkinson, H. J., Urwin, P. E., Differential gene expression in Arabidopsis following infection by plant-parasitic nematodes Meloidogyne incognita and Heterodera schachtii. Mol. Plant Pathol. 2007, 8, 595-609.

[31] Bhattarai, K. K., Xie, Q.-G., Mantelin, S., Bishnoi, U. et al., Tomato susceptibility to root-knot nematodes requires an intact jasmonic acid signaling pathway. Mol. Plant-Microbe Interact. 2008, 21, 1205-1214.
[32] Beneventi, M., da Silva, O., de Sá, M. E., Firmino, A. A. et al., Transcription profile of soybean-root-knot nematode interaction reveals a key role of phythormones in the resistance reaction. BMC Genomics 2013, 14, 322.

[33] Kaloshian, I., Desmond, O., Atamian, H., in: Jones, J., Gheysen, G., Fenoll, C. (Eds.), Genomics and Molecular Genetics of Plant-Nematode Interactions, Springer, the Netherlands 2011, pp. 309-324.

[34] Kurepa, J., Wang, S., Li, Y., Smalle, J., Proteasome regulation, plant growth and stress tolerance. Plant Signal. Behav. 2009, 4, 924-927.

[35] Berlett, B. S., Stadtman, E. R., Protein oxidation in aging, disease, and oxidative stress. J. Biol. Chem. 1997, 272, $20313-$ 20316.

[36] Bochtler, M., Ditzel, L., Groll, M., Hartmann, C., Huber, R., The proteasome. Annu Rev Biophys Biomol Struct. 1999, 28, 295-317.

[37] Afzal, A. J., Natarajan, A., Saini, N., Iqbal, M. J. et al., The nematode resistance allele at the rhg1 locus alters the proteome and primary metabolism of soybean roots. Plant Physiol. 2009, 151, 1264-1280.

[38] Carmo, L. S. T., Resende, R. O., Silva, L. P., Ribeiro, S. G., Mehta, A., Identification of host proteins modulated by the virulence factor $\mathrm{AC} 2$ of Tomato chlorotic mottle virus in Nicotiana benthamiana. Proteomics 2013, 13, 1947-1960.

[39] Baxter, A., Mittler, R., Suzuki, N., ROS as key players in plant stress signalling. J. Exp. Bot. 2014, 65, 1229-1240.

[40] Rojas, C. M., Senthil-Kumar, M., Wang, K., Ryu, C.-M. et al., Glycolate oxidase modulates reactive oxygen speciesmediated signal transduction during nonhost resistance in Nicotiana benthamiana and Arabidopsis. Plant Cell Online 2012, 24, 336-352.

[41] Turóczy, Z., Kis, P., Török, K., Cserháti, M. et al., Overproduction of a rice aldo-keto reductase increases oxidative and heat stress tolerance by malondialdehyde and methylglyoxal detoxification. Plant Mol. Biol. 2011, 75, 399-412.

[42] Supuran, C., Carbonic anhydrases-an overview. Curr. Pharm. Des. 2008, 14, 603-614.

[43] Subramanian, B., Bansal, V. K., Kav, N. N. V., Proteome-level investigation of Brassica carinata-derived resistance to Leptosphaeria maculans. J. Agric. Food Chem. 2004, 53, 313324.

[44] Slaymaker, D. H., Navarre, D. A., Clark, D., del Pozo, O. et al., The tobacco salicylic acid-binding protein 3 (SABP3) is the chloroplast carbonic anhydrase, which exhibits antioxidant activity and plays a role in the hypersensitive defense response. Proc. Natl. Acad. Sci. 2002, 99, 11640-11645.

[45] Chitwood, D. J., Phytochemical based strategies for nematode control1. Ann. Rev. Phytopathol. 2002, 40, 221-249.

[46] Hewezi, T., Howe, P. J., Maier, T. R., Hussey, R. S. et al., Arabidopsis spermidine synthase is targeted by an effector protein of the cyst nematode Heterodera schachtii. Plant Physiol. 2010, 152, 968-984.

[47] Kasukabe, Y., He, L., Nada, K., Misawa, S. et al., Overexpression of spermidine synthase enhances tolerance to multiple environmental stresses and up-regulates the expression 
of various stress-regulated genes in transgenic Arabidopsis thaliana. Plant Cell Physiol. 2004, 45, 712-722.

[48] Kissen, R., Bones, A. M., Nitrile-specifier proteins involved in glucosinolate hydrolysis in Arabidopsis thaliana. J. Biol. Chem. 2009, 284, 12057-12070.

[49] Andrews, D. L., Beames, B., Summers, M. D., Park, W. D., Characterization of the lipid acyl hydrolase activity of the major potato (Solanum tuberosum) tuber protein, patatin, by cloning and abundant expression in a baculovirus vector. Biochem. J. 1988, 252, 199-206.

[50] Strickland, J. A., Orr, G. L., Walsh, T. A., Inhibition of diabrotica larval growth by patatin, the lipid acyl hydrolase from potato tubers. Plant Physiol. 1995, 109, 667-674.

[51] Camera, S. L., Balagué, C., Göbel, C., Geoffroy, P. et al., The arabidopsis patatin-like protein 2 (PLP2) plays an essential role in cell death execution and differentially affects biosynthesis of oxylipins and resistance to pathogens. Mol. PlantMicrobe Interact. 2009, 22, 469-481.

[52] Bittner-Eddy, P. D., Crute, I. R., Holub, E. B., Beynon, J. L., RPP13 is a simple locus in Arabidopsis thaliana for alleles that specify downy mildew resistance to different avirulence determinants in Peronospora parasitica. Plant J. 2000, 21, 177-188.

[53] Desimone, M., Henke, A., Wagner, E., Oxidative stress induces partial degradation of the large subunit of ribulose-1,5-bisphosphate carboxylase/oxygenase in isolated chloroplasts of barley. Plant Physiol. 1996, 111, 789-796.

[54] van Cleve, B., Forreiter, C., Sauter, J., Apel, K., Pith cells of poplar contain photosynthetically active chloroplasts. Planta 1993, 189, 70-73.

[55] Foyer, C. H., Theodoulou, F. L., Delrot, S., The functions of inter- and intracellular glutathione transport systems in plants. Trends Plant Sci. 2001, 6, 486-492.
[56] Dao, T. T. H., Linthorst, H. J. M., Verpoorte, R., Chalcone synthase and its functions in plant resistance. Phytochem. Rev. 2011, 10, 397-412.

[57] Van Leene, J., Boruc, J., DeJaeger, G., Russinova, E., De Veylder, L., A kaleidoscopic view of the Arabidopsis core cell cycle interactome. Trends Plant Sci. 2011, 16, 141-150.

[58] Boyd, R. S., Martens, S. N. in: Baker, A. J. M., Proctor J., Reeves, R. D. (Eds.), The Vegetation of Ultramafic (Serpentine) Soils, Intercept Limited, Andover, Hampshire, UK 1992, pp. 279-289.

[59] Poschenrieder, C., Tolrà, R., Barceló, J., Can metals defend plants against biotic stress? Trends Plant Sci. 2006, 11, 288295.

[60] Ghaderian, Y. S. M., Lyon, A. J. E., Baker, A. J. M., Seedling mortality of metal hyperaccumulator plants resulting from damping off by Pythium spp. New Phytol. 2000, 146, 219224.

[61] Boyd, R. S., Shaw, J. J., Martens, S. N., Nickel hyperaccumulation defends Streptanthus polygaloides (Brassicaceae) against pathogens. Am. J. Bot. 1994, 81, 294-300.

[62] Fones, H., Davis, C. A. R., Rico, A., Fang, F. et al., Metal hyperaccumulation armors plants against disease. PLoS Pathog. 2010, 6, e1001093.

[63] Singh, J., Hembram, P., Basak, J., Potential of Vigna unguiculata as a phytoremediation plant in the remediation of $\mathrm{Zn}$ from contaminated soil. Am. J. Plant Sci. 2014, 5, 1156-1162.

[64] Das, S., Ehlers, J., Close, T., Roberts, P., Transcriptional profiling of root-knot nematode induced feeding sites in cowpea (Vigna unguiculata L. Walp.) using a soybean genome array. BMC Genomics 2010, 11, 480.

[65] Lackner, D., Schmidt, M., Wu, S., Wolf, D., Bahler, J., Regulation of transcriptome, translation, and proteome in response to environmental stress in fission yeast. Genome Biol. 2012, 13, R25. 